\title{
MANDATE AND REPRESENTATION
}

\author{
Dana-Lucia TULAI ${ }^{\text {** }}$ \\ a) Babeș-Bolyai University, Faculty of Economics and Business Administration, \\ Cluj-Napoca, Romania
}

Please cite this article as:

Article History:

Tulai, D.L., 2020. Mandate and representation. Received: 10 September 2020 Review of Economic Studies and Research Virgil Accepted: 31 October 2020 Madgearu, 13(2), pp.199-222.

doi: 10.24193/RVM.2020.13.68.

Abstract: The mandate contract, although it bears similarities to other types of conventions and legal institutions, is unequivocally different in its specific features. In our article, we shall try to distinguish the mandate from representation, a legal institution with which it shares similarities that have generated doctrinal discussions. We believe that the usefulness of this approach is justified all the more since representation has received its own legal regulation under the new Romanian Civil Code, for the first time in our civil law. The conclusion of our study is that representation is not the essence of the mandate, but only characterizes its nature, since there is mandate without representation, as well as representation without mandate.

Key words: mandate; representation; agent; principal; prête-nom; power of attorney

JEL Classification: K12; K15; K22

(C) 2020 Alma Mater Publishing House. All rights reserved.

Corresponding author. E-mail address: dana.tulai@econ.ubbcluj.ro. 
Review of Economic Studies and Research Virgil Madgearu, 2020, 13(2)

\section{References:}

1. Baias, F.A., 2003. Simulația. Studiu de doctrină și jurisprudență. București: Rosetti.

2. Cărpenaru, S.D., 2012. Tratat de drept comercial român conform noului Cod civil. București: Universul Juridic.

3. Cosma, D., 1969. Teoria generală a actului juridic civil. București: Ed. Științifică.

4. Deak, F., 1999. Tratat de drept civil. Contracte speciale. $2^{\text {nd }}$ ed. București: Actami.

5. Firică, C., 2013. Excepții de la principiul relativităţii efectelor contractului. București: C. H. Beck.

6. Georgescu, I.L., 1946. Drept comercial român. Vol. I. București: Socec.

7. Laurent, F., 1887. Principes de droit civil français. Tome XXVII. 4e éd. Bruxelles: Bruylant-Christophe \& Co.

8. Malaurie, P., Aynès, L. and Gautier, P.Y., 2009. Drept civil. Contractele speciale. București: Wolters Kluwer.

9. Martin, D.R., 2003. Note to Cass 1re civ., 5 fev. 2002. La Semaine Juridique Éd. Générale, no. 9.

10. Najjar, I., 2003. Mandat et irrévocabilité. Dalloz, no. 11

11. Pétel, P., 1994. Le contrat de mandat. Paris: Dalloz.

12. Planiol, M. and Ripert, G., 1932. Traité pratique de droit civil français. Contrats civils. Paris: L.G.D.J.

13. Pop, A. and Beleiu, G., 1980. Drept civil. Teoria generală a dreptului civil. Univ. București.

14. Pop, L., 2009. Tratat de drept civil. Obligațiile. Vol. II. Contractul. București: Universul Juridic.

15. Popa-Nistorescu, C., 2013. Considerații cu privire la contractul de Agency. Pandectele române, 3, pp.44-48.

16. Popescu, T.R., 1976. Dreptul comerțului internațional. București: Ed. Didactică și Pedagogică.

17. Rizoiu, R., 2009. Mandatul irevocabil ca tehnică de garantare a obligațiilor. Revista română de drept privat, 4, pp.180-234.

18. Stoica, L.C., 2010. Mandatul. Reprezentarea judiciară. Practică judiciară. București: Hamangiu.

19. Supreme Court, 1971. Culegere de decizii ale Tribunalului Suprem pe anul 1970. București: Ed. Științifică. 
20. Supreme Court, 1973. Culegere de decizii ale Tribunalului Suprem pe anul 1972. București: Ed. Științifică.

21. Supreme Court. Civil decision no. 457/1977. In Revista română de drept, 5/1978, p.50.

22. Supreme Court, 2010. Civil decision no. 267/2009. In Revista română de jurisprudență, 2010, p.148.

23. Vasile, C.D., 2011. Reprezentarea persoanelor în actele juridice civile. Craiova: Sitech. 